\title{
Sistem Pendukung Keputusan Penerimaan Beasiswa Peningkatan Prestasi Akademik (PPA) Berbasis Web
}

\author{
Sariati $^{1)}$, Winda Aprianti ${ }^{2)}$, Fathurrahmani ${ }^{3)}$ \\ ${ }^{122) 3)}$ Jurusan Teknik Informatika Politeknik Negeri Tanah Laut \\ Jl. A.Yani Km.06 Ds. Panggung Pelaihari \\ 1) sariati1497@gmail.com \\ 2)winda@politala.ac.id \\ 3)fathurrahmani@politala.ac.id
}

\begin{abstract}
Abstrak
Penentuan keputusan penerimaan beasiswa Peningkatan Prestasi Akademik (PPA) pada program studi Teknik Informatika masih dilakukan secara konvensional oleh bagian kemahasiswaan institusi dan program studi, yakni dengan cara pengumpulan berkas, pemasukan dan penghitungan data pada Microsoft Excel, dan penyeleksian berdasarkan hasil perhitungan data. Besarnya jumlah pendaftar beasiswa berakibat pada tidak efisiennya proses penerimaan beasiswa yang berjalan saat ini sehingga perlu sebuah sistem yang dapat mendukung keputusan penerimaan beasiswa PPA. Sistem berbasis web yang diusulkan menggunakan metode weighted product dalam penentuan perankingan pendaftar beasiswa. Kriteria yang digunakan dalam permasalahan penentuan beasiswa PPA meliputi Indeks Prestasi Kumulatif (IPK), penghasilan orang tua, dan jumlah tanggungan. Hasil penerapan weighted product terhadap data sampel pendaftar beasiswa di Program Studi Teknik Informatika pada tahun 2017 memberikan informasi perankingan pendaftar beasiswa dimana Mahasiswa 3 mendapat ranking pertama yang artinya mendapat prioritas paling pertama sebagai penerima beasiswa PPA. Sistem yang dibangun telah menampilkan hasil penerapan weigted product dan tampilan grafi yang memudahkan pengguna memperoleh informasi mengenai pendaftaran beasiswa PPA.
\end{abstract}

Kata kunci: penerima beasiswa, sistem pendukung keputusan, weighted product

\begin{abstract}
Determination of the decision thatrecipient of Academic Achievement Improvement scholarships in the Informatics Engineering is still done conventionally by the student division at the institutional and study program level, namely by collecting files, inputting and calculating data in Microsoft Excel, and selecting based on the data calculation results. The large number of scholarship applicants results in the inefficiency of the scholarship admission process so that it needs a system that can support the decision to receive scholarships. The proposed web-based system uses the weighted product method in determining the ranking of scholarship applicants. The criteria used in the problem of determining the scholarship include the Grade Point Average (GPA), parents' income, and the number of dependents. The results of applying weighted products to sample data of scholarship applicants in the Informatics Engineering in 2017 provide ranking information for scholarship applicants where Student 3 gets first rank, which means getting the first priority as a recipient of scholarship. The system that was built has displayed the results of the application of weigted products and graphical displays that make it easier for users to obtain information about the registration of scholarships.
\end{abstract}

Keywords: scholarship recipient, decision support system, weighted product 


\section{PENDAHULUAN}

Beasiswa Peningkatan Prestasi Akademik (PPA) merupakan bantuan beasiswa dari pemerintah kepada mahasiswa di perguruan tinggi, terutama yang mempunyai prestasi akademik. Politeknik Negeri Tanah Laut sebagai salah satu perguruan tinggi negeri setiap tahunnya memperoleh kuota untuk beasiswa PPA. Pengelolaan beasiswa ini kemudian dipercayakan kepada masing-masing program studi, yakni Teknik Informatika, Teknologi Industri Pertanian, Mesin Otomotif, dan Akuntansi. Pengelolaan beasiswa yang menjadi tanggung jawab masing-masing program studi mempunyai tingkat kesulitan yang berbeda. Program studi Teknik Informatika dengan jumlah mahasiswa terbanyak di Politeknik Negeri Tanah Laut, yakni 323 mahasiswa yang terdata aktif pada semester genap Tahun Akademik 2017/2018 mempunyai tingkat kesulitan yang lebih tinggi dibandingkan program studi lainnya.

Pengelolaan beasiswa pada program studi Teknik Informatika dimulai dari proses pendaftaran dimana mahasiswa pendaftar beasiswa mengumpulkan berkas-berkas persyaratan beasiswa ke bagian kemahasiswaan Politeknik Negeri Tanah Laut. Berkas tersebut kemudian diserahkan kembali ke program studi Teknik Informatika untuk masuk ke proses penilaian. Hasil penilaian pada berkas-berkas yang dikumpulkan kemudian dimasukkan dan dihitung pada Microsoft Excel oleh pihak kemahasiswaan program studi Teknik Informatika. Hasil perhitungan tersebut kemudian diseleksi untuk diambil keputusan mahasiswa yang berhak menerima beasiswa PPA. Banyaknya jumlah mahasiswa di program studi Teknik Informatika juga berdampak pada jumlah pendaftar beasiswa PPA dimana pada tahun 2017 terdata sebanyak 55 orang. Hal ini membuat pihak kemahasiswaan kesulitan dalam memeriksa berkas yang selanjutnya akan dimasukkan ke Microsoft Excel dan menentukan penerima beasiswa yang benar-benar memenuhi kriteria.

Guna mengatasi permasalahan kesulitan menentukan penerima beasiswa, diperlukan adanya sistem yang dapat mendukung dalam proses pengambilan keputusan. Sistem pengambilan keputusan menggunakan metodeweighted product untuk penentuan beasiswa telah dilakukan oleh Damanik dan Hutagalung (2017) menggunakan lima kriteria, yakni penghasilan orang tua, semester, jumlah tanggungan, jumlah saudara kandung, dan indeks prestasi mahasiswa. Penelitian ini menghasilkan bahwa indeks prestasi mahasiswa bukan prioritas dalam pemberian beasiswa. Pemilihan metodeweighted product karena performanya dalam sistem perankingan sangat baik karena menggunakan perkalian dari nilai rating kinerja yang dipangkatkan dengan nilai bobot yang terlah diperbaiki sehingga urutan ranking yang diberikan lebih tepat dengan hasil yang spesifik (Setyawan, 2017). Sedangkan untuk mengatasi permasalahan ketidakefisienan pendaftaran beasiswa PPA perlu adanya sistem berbasis web yang dapat membantu pihak pengurus dan mahasiswa dalam proses pendaftaran. Oleh karena itu, dibuatlah Sistem Pendukung Keputusan Penerimaan Beasiswa Peningkatan Prestasi Akademik (PPA) Berbasis Web.

\section{TINJAUAN PUSTAKA}

Weighted product merupakan salah satu metode pada sistem pendukung keputusan dimana sistem pendukung keputusan menurut Nofriansyah (2015) dan Pratiwi (2016) merupakan sistem informasi berbasis komputer yang dibangun untuk dapat memberikan solusi dari permasalahan secara objektif berdasarkan kriteria yang telah ditetapkan.

Weighted product adalah metode pendukung keputusan dengan cara mengalikan rating setiap atribut yang telah dipangkatkan dengan nilai bobot terlebih dahulu. Langkah-langkah dalam perhitungan metode weighted product adalah sebagai berikut:

i. melakukan perbaikan bobot menggunakan Persamaan (1)

Keterangan untuk Persamaan (1):

$$
w_{j}=\frac{w_{j}}{\sum_{j=1}^{m} w_{j}}
$$

$w_{j}=$ bobot perbaikan pada kriteria $j$ yang diperoleh menggunakan Persamaan (2).

$j \quad=$ kriteria

$m$ = banyaknya kriteria 
ii. mengalikan seluruh atribut bagi seluruh alternatif dengan bobot

iii. hasil perkalian dijumlahkan untuk menghasilkan nilai pada setiap alternatif

iv. membagi nilai preferensi bagi setiap alternatif dengan nilai pada setiap alternatif

v. ditemukan urutan alternatif terbaik yang akan menjadi keputusan

Langkah (ii) dan (iii) menggunakan Persamaan (2).

$$
S_{i}=\prod_{j=1}^{m} x_{i j}{ }^{w_{j}}
$$

Keterangan untuk Persamaan (2):

$S_{i}=$ hasil perkalian ratingkinerja dianalogikan sebagai Vektor $\mathrm{S}$

$x_{i j}=$ nilai rating kinerja pada alternatif $i$ dan kriteria $j$

$w_{j}=$ bobot perbaikan pada kriteria $j$

$i=$ alternatif

$j \quad=$ kriteria

$m$ = banyaknya kriteria

Langkah (iv) menggunakan Persamaan (3).

$$
V_{i}=\frac{S_{i}}{\sum_{i=1}^{n} S_{i}}
$$

Keterangan untuk Persamaan (3):

$V_{i}=$ preferensi alternatif $i$ dianalogikan sebagai Vektor $\mathrm{S}$

$S_{i}=$ hasil perkalian rating kinerja dianalogikan sebagai Vektor $\mathrm{S}$

$i=$ alternatif

$n \quad=$ banyaknya alternatif

\section{METODE PENELITIAN}

Tahapan metode penelitian diuraikan sebagai berikut.

i. Pengumpulan Data

Data yang dikumpulkan merupakan data sekunder pendaftaran beasiswa mahasiswa program studi Teknik Informatika pada tahun 2017 yang diperoleh dari bidang kemahasiswaan Politeknik Negeri Tanah Laut dan kemahasiswaan program studi Teknik Informatika.

ii. Penentuan Kriteria dan Bobot

Data yang diperoleh kemudian dilakukan pemilihan data yang dijadikan kriteria dan diberikan bobot pada data terpilih.

iii. Penerapan Weighted Product

Tahap ini merupakan penerapan weighted product yang telah diuraikan pada subbab 2.1 pada data pendaftaran beasiswa

iv. Pembangunan Sistem Berbasis Web

Tahap ini merupakan pembangunan sistem menggunakan bahasa pemrograman hypertext preprocessor (PHP).

\section{PEMBAHASAN}

\subsection{Pengumpulan Data}

Data sekunder diperoleh dari berkas pendaftaran beasiswa pada tahun 2017 yang berjumlah 55 orang pendaftar. Berkas pendaftaran yang dikumpulkan terdiri dari:

a. Formulir pendaftaran beasiswa PPA

b. Surat keterangan tidak mampu

c. Slip tagihan listrik

d. Slip gaji orang tua

e. Fotokopi Kartu Hasil Studi (KHS) terbaru 
f. Fotokopi Kartu Rencana Studi (KRS) terbaru

g. Fotokopi kartu keluarga

h. Transkrip nilai terbaru

i. Fotokopi kartu tanda mahasiswa (KTM)

j. Foto rumah terbaru

k. Surat keterangan mahasiswa

\subsection{Penentuan Kriteria dan Bobot}

Berdasarkan pengumpulan data dari berkas pendaftaran beasiswa pada tahun 2017, program studi Teknik Informatika menggunakan tiga kriteria, yakni indeks prestasi kumulatif (IPK) yang diperoleh dari transkrip nilai terbaru, penghasilan orang tua yang diperoleh dari slip gaji orang tua dan jumlah tanggungan yang diperoleh dari kartu keluarga.

IPK menjadi salah satu kriteria yang digunakan untuk menentukan penilaian terhadap penerimaan beasiswa PPA. IPK merupakan kriteria dengan bobot tertinggi, yang berarti IPK merupakan kriteria paling penting dalam penilaian ini. IPK dianggap penting karena dapat memberikan gambaran prestasi mahasiswa pendaftar beasiswa PPA.

Penghasilan orang tua juga merupakan salah satu kriteria dalam menentukan penilaian terhadap calon penerima beasiswa. Penghasilan orang tua ini dihitung dari jumlah penghasilan kedua orang tua mahasiswa pendaftar beasiswa PPA. Semakin tinggi jumlah penghasilan orang tua, maka semakin kecil kesempatan untuk mahasiswa tersebut mendapat beasiswa PPA.

Kriteria terakhir yang digunakan dalam menentukan penerimaan beasiswa PPA pada program studi Teknik Informatika adalah jumlah tanggungan keluarga. Semakin banyak jumlah tanggungan dalam satu keluarga, maka semakin banyak pula jumlah biaya yang harus dikeluarkan tiap bulannya.

Kriteria dan masing-masing bobot kriterianya disajikan pada Tabel 2.

Tabel 2. Tabel kriteria dan bobot

\begin{tabular}{|l|c|c|}
\hline \multicolumn{1}{|c|}{ Kriteria Penilaian } & Inisial & Bobot \\
\hline IPK & $\mathrm{C} 1$ & 40 \\
\hline Penghasilan Orang Tua & $\mathrm{C} 2$ & 30 \\
\hline Jumlah Tanggungan & $\mathrm{C} 3$ & 30 \\
\hline
\end{tabular}

\subsection{Penerapan Weighted Product}

Metode weighted product diterapkan pada data sampel yang diambil secara acak sebanyak 25 data. Data sampel ditunjukkan pada Tabel 3.

Tabel 3. Data sampel pendaftar beasiswa

\begin{tabular}{|c|c|c|r|}
\hline \multirow{2}{*}{ Alternatif } & \multicolumn{3}{|c|}{ Kriteria } \\
\cline { 2 - 4 } & C1 & C2 & \multicolumn{1}{c|}{ C3 } \\
\hline Mahasiswa 1 & 3.74 & 5 & 1.500 .000 \\
\hline Mahasiswa 2 & 3.33 & 2 & 1.000 .000 \\
\hline Mahasiswa 3 & 3.56 & 5 & 700.000 \\
\hline Mahasiswa 4 & 3.48 & 1 & 2.000 .000 \\
\hline Mahasiswa 5 & 3.50 & 3 & 1.000 .000 \\
\hline Mahasiswa 6 & 3.47 & 5 & 1.000 .000 \\
\hline Mahasiswa 7 & 3.30 & 3 & 500.000 \\
\hline Mahasiswa 8 & 3.46 & 4 & 2.774 .200 \\
\hline Mahasiswa 9 & 3.81 & 3 & 1.500 .000 \\
\hline Mahasiswa 10 & 3.70 & 3 & 900.000 \\
\hline Mahasiswa 11 & 3.71 & 2 & 1.500 .000 \\
\hline Mahasiswa 12 & 3.65 & 2 & 1.500 .000 \\
\hline Mahasiswa 13 & 3.59 & 3 & 750.000 \\
\hline
\end{tabular}

\begin{tabular}{|c|r|r|r|}
\hline \multirow{2}{*}{ Alternatif } & \multicolumn{3}{|c|}{ Kriteria } \\
\cline { 2 - 4 } & C1 & \multicolumn{1}{|c|}{ C2 } & \multicolumn{1}{c|}{ C3 } \\
\hline Mahasiswa 14 & 3.42 & 2 & 1.000 .000 \\
\hline Mahasiswa 15 & 3.15 & 5 & 750.000 \\
\hline Mahasiswa 16 & 3.56 & 2 & 500.000 \\
\hline Mahasiswa 17 & 3.89 & 1 & 750.000 \\
\hline Mahasiswa 18 & 3.81 & 3 & 1.500 .000 \\
\hline Mahasiswa 19 & 3.90 & 4 & 1.500 .000 \\
\hline Mahasiswa 20 & 3.50 & 1 & 1.500 .000 \\
\hline Mahasiswa 21 & 3.86 & 2 & 600.000 \\
\hline Mahasiswa 22 & 3.74 & 3 & 2.000 .000 \\
\hline Mahasiswa 23 & 3.67 & 2 & 1.500 .000 \\
\hline Mahasiswa 24 & 3.90 & 2 & 1.000 .000 \\
\hline Mahasiswa 25 & 3.90 & 2 & 1.000 .000 \\
\hline
\end{tabular}


Langkah awal adalah melakukan perbaikan bobot yang ditampilkan pada Tabel 2 menggunakan Persamaan (1). Perbaikan untuk bobot kriteria $1\left(w_{1}\right)$, yakni 40 diberikan sebagai berikut.

$$
w_{1}=\frac{w_{1}}{\sum_{j=1}^{3} w_{j}}=\frac{40}{40+30+30}=0,4
$$

Dengan cara yang sama, didapatkan perbaikan bobot yang disajikan pada Tabel 4.

Tabel 4. Hasil perbaikan bobot

\begin{tabular}{|c|c|c|}
\hline Keterangan & Simbol & Perbaikan Bobot \\
\hline Bobot kriteria 1 & $w_{1}$ & 0,4 \\
\hline Bobot kriteria 2 & $w_{2}$ & 0,3 \\
\hline Bobot kriteria 3 & $w_{3}$ & 0,3 \\
\hline
\end{tabular}

Selanjutnya adalah menghitung vektor $S$ menggunakan Persamaan (2). Perhitungan vektor $S$ untuk Mahasiswa 1 diberikan sebagai berikut.

$$
S_{1}=\prod_{j=1}^{3} x_{1 j}{ }^{w_{j}}=x_{11}{ }^{w_{1}} \times x_{12}{ }^{w_{2}} \times x_{13}{ }^{w_{3}}=3,74^{0,4} \times 5^{0,3} \times 1500000^{0,3}=0,0385
$$

Dengan cara yang sama, didapatkan nilai vektor $S$ untuk setiap alternatif pendaftar beasiswa PPA yang disajikan pada Tabel 5.

Tabel 5. Hasil perhitungan nilai vektor $S$

\begin{tabular}{|c|c|}
\hline Alternatif & Vektor $\boldsymbol{S}$ \\
\hline Mahasiswa 1 & 0,0385 \\
\hline Mahasiswa 2 & 0,0315 \\
\hline Mahasiswa 3 & 0,0474 \\
\hline Mahasiswa 4 & 0,0212 \\
\hline Mahasiswa 5 & 0,0363 \\
\hline Mahasiswa 6 & 0,0421 \\
\hline Mahasiswa 7 & 0,0437 \\
\hline Mahasiswa 8 & 0,0291 \\
\hline Mahasiswa 9 & 0,0332 \\
\hline Mahasiswa 10 & 0,0385 \\
\hline Mahasiswa 11 & 0,0291 \\
\hline Mahasiswa 12 & 0,0289 \\
\hline Mahasiswa 13 & 0,0401 \\
\hline
\end{tabular}

\begin{tabular}{|l|l|}
\hline Alternatif & Vektor $\boldsymbol{S}$ \\
\hline Mahasiswa 14 & 0,0318 \\
\hline Mahasiswa 15 & 0,0444 \\
\hline Mahasiswa 16 & 0,0399 \\
\hline Mahasiswa 17 & 0,0298 \\
\hline Mahasiswa 18 & 0,0332 \\
\hline Mahasiswa 19 & 0,0366 \\
\hline Mahasiswa 20 & 0,0231 \\
\hline Mahasiswa 21 & 0,0391 \\
\hline Mahasiswa 22 & 0,0304 \\
\hline Mahasiswa 23 & 0,0290 \\
\hline Mahasiswa 24 & 0,0335 \\
\hline Mahasiswa 25 & 0,0335 \\
\hline
\end{tabular}

Setelah nilai vektor $S$ didapat, maka selanjutnya adalah menghitung nilai preferensi menggunakan Persamaan (3). Berikut perhitungan $V$ untuk Mahasiswa 1.

$$
V_{1}=\frac{S_{1}}{\sum_{i=1}^{25} S_{i}}=\frac{S_{1}}{S_{1}+S_{2}+\cdots+S_{25}}=\frac{0,0385}{0,0385+0,0315+\cdots+0,0335}=0,0446
$$

Dengan cara yang sama didapatkan nilai preferensi $V$ untuk setiap alternatif pendaftar beasiswa PPA yang disajikan pada Tabel 6 .

Tabel 6. Hasil perhitungan nilai preferensi $V$

\begin{tabular}{|c|c|}
\hline Alternatif & Nilai Preferensi \\
\hline Mahasiswa 1 & 0,0446 \\
\hline Mahasiswa 2 & 0,0365 \\
\hline Mahasiswa 3 & 0,0549 \\
\hline
\end{tabular}

\begin{tabular}{|l|c|}
\hline Alternatif & Nilai Preferensi $\boldsymbol{V}$ \\
\hline Mahasiswa 14 & 0,0368 \\
\hline Mahasiswa 15 & 0,0514 \\
\hline Mahasiswa 16 & 0,0462 \\
\hline
\end{tabular}




\begin{tabular}{|c|c|}
\hline Alternatif & Nilai Preferensi \\
\hline Mahasiswa 4 & 0,0245 \\
\hline Mahasiswa 5 & 0,0420 \\
\hline Mahasiswa 6 & 0,0487 \\
\hline Mahasiswa 7 & 0,0506 \\
\hline Mahasiswa 8 & 0,0337 \\
\hline Mahasiswa 9 & 0,0384 \\
\hline Mahasiswa 10 & 0,0446 \\
\hline Mahasiswa 11 & 0,0337 \\
\hline Mahasiswa 12 & 0,0335 \\
\hline Mahasiswa 13 & 0,0464 \\
\hline
\end{tabular}

\begin{tabular}{|l|c|}
\hline Alternatif & Nilai Preferensi $\boldsymbol{V}$ \\
\hline Mahasiswa 17 & 0,0345 \\
\hline Mahasiswa 18 & 0,0384 \\
\hline Mahasiswa 19 & 0,0424 \\
\hline Mahasiswa 20 & 0,0267 \\
\hline Mahasiswa 21 & 0,0453 \\
\hline Mahasiswa 22 & 0,0352 \\
\hline Mahasiswa 23 & 0,0336 \\
\hline Mahasiswa 24 & 0,0388 \\
\hline Mahasiswa 25 & 0,0388 \\
\hline
\end{tabular}

Langkah terakhir adalah mengurutkan hasil nilai preferensi $V$ pada Tabel 6 dari nilai terbesar ke nilai terkecil, sehingga diperoleh perankingan yang disajikan pada Tabel 7.

Tabel 7. Hasil perankingan nilai preferensi $V$

\begin{tabular}{|c|l|c|}
\hline Ranking & \multicolumn{1}{|c|}{ Alternatif } & Nilai Preferensi $\boldsymbol{V}$ \\
\hline 1 & Mahasiswa 3 & 0,0549 \\
\hline 2 & Mahasiswa 15 & 0,0514 \\
\hline 3 & Mahasiswa 7 & 0,0506 \\
\hline 4 & Mahasiswa 6 & 0,0487 \\
\hline 5 & Mahasiswa 13 & 0,0464 \\
\hline 6 & Mahasiswa 16 & 0,0462 \\
\hline 7 & Mahasiswa 21 & 0,0453 \\
\hline 8 & Mahasiswa 1 & 0,0446 \\
\hline 9 & Mahasiswa 10 & 0,0446 \\
\hline 10 & Mahasiswa 19 & 0,0424 \\
\hline 11 & Mahasiswa 5 & 0,0420 \\
\hline 12 & Mahasiswa 25 & 0,0388 \\
\hline 13 & Mahasiswa 24 & 0,0388 \\
\hline
\end{tabular}

\begin{tabular}{|c|l|c|}
\hline Ranking & Alternatif & Nilai Preferensi $\boldsymbol{V}$ \\
\hline 14 & Mahasiswa 18 & 0,0384 \\
\hline 15 & Mahasiswa 9 & 0,0384 \\
\hline 16 & Mahasiswa 14 & 0,0368 \\
\hline 17 & Mahasiswa 2 & 0,0365 \\
\hline 18 & Mahasiswa 22 & 0,0352 \\
\hline 19 & Mahasiswa 17 & 0,0345 \\
\hline 20 & Mahasiswa 8 & 0,0337 \\
\hline 21 & Mahasiswa 11 & 0,0337 \\
\hline 22 & Mahasiswa 23 & 0,0336 \\
\hline 23 & Mahasiswa 12 & 0,0335 \\
\hline 24 & Mahasiswa 20 & 0,0267 \\
\hline 25 & Mahasiswa 4 & 0,0267 \\
\hline
\end{tabular}

Berdasarkan Tabel 7 dapat diambil keputusan mahasiswa pendaftar yang berhak menerima beasiswa PPA. Jika kuota penerima beasiswa sebanyak 10 orang, maka mahasiswa dari ranking 1 sampai dengan 10 berhak mendapat beasiswa, yakni Mahasiswa 3 sampai dengan Mahasiswa 19.

Alur penerapan weighted product ini kemudian diimplementasikan dalam pembangunan sistem pendukung keputusan penerimaan beasiswa PPA berbasis web pada subbab 4.4.

\subsection{Pembangunan Sistem Berbasis Web \\ 4.4.1 Implementasi Halaman Login}

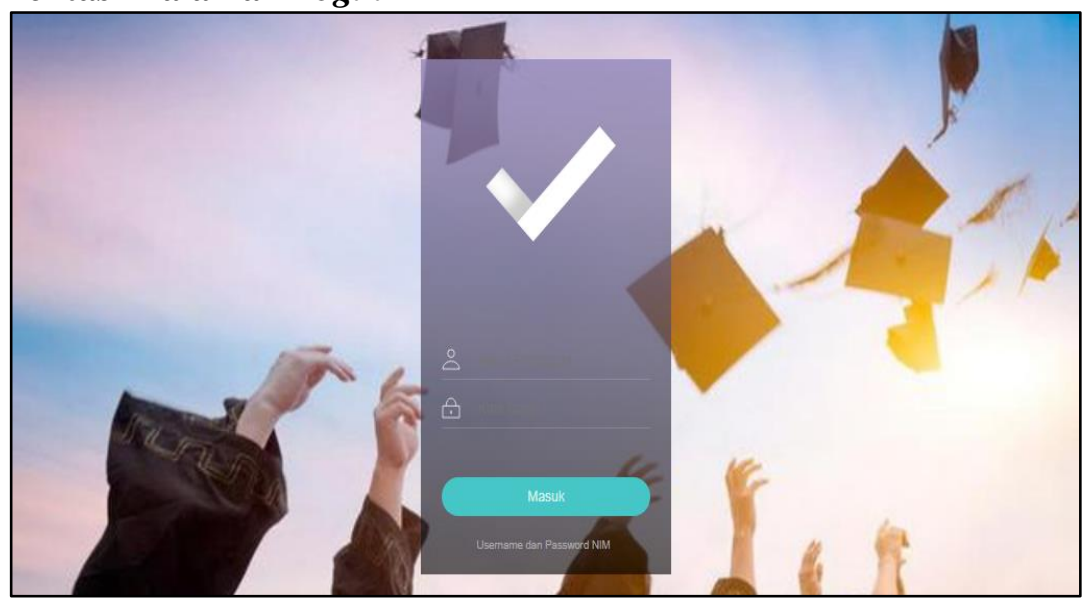

Gambar 1. Implementasi halaman login 
Gambar 1 menunjukan tampilan halaman login dimana pengguna harus memasukkan username dan password yang benar dan menekan tombol masuk untuk dapat mengakses sistem pendukung keputusan penerimaan beasiswa PPA.

Implementasi halaman penerapan metode weighted product dan tampilan grafik dapat dilihat pada Gambar 2 sampai dengan Gambar 10.

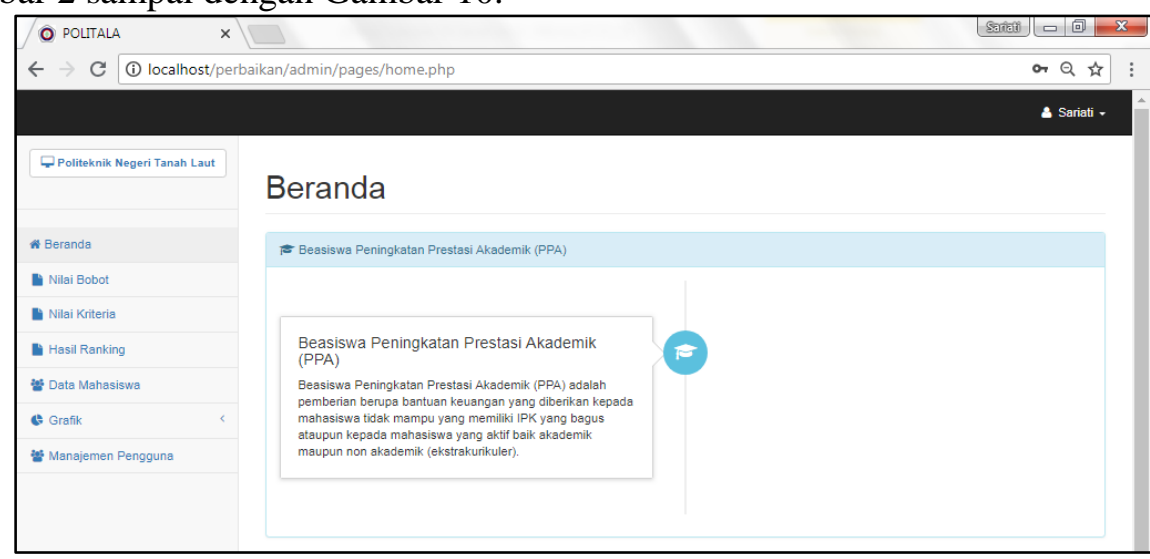

Gambar 2. Implementasi halaman beranda

Gambar 2 menunjukan tampilan halaman beranda untuk admin dimana admin dapat memilih tindakan apa yang akan dilakukannya. Beberapa tindakan yang dapat admin lakukan diantaranya mengelola data bobot, mengelola data kriteria, melihat hasil perankingan, mengelola biodata mahasiswa, melihat grafik per kriteria, dan mengelola pengguna.
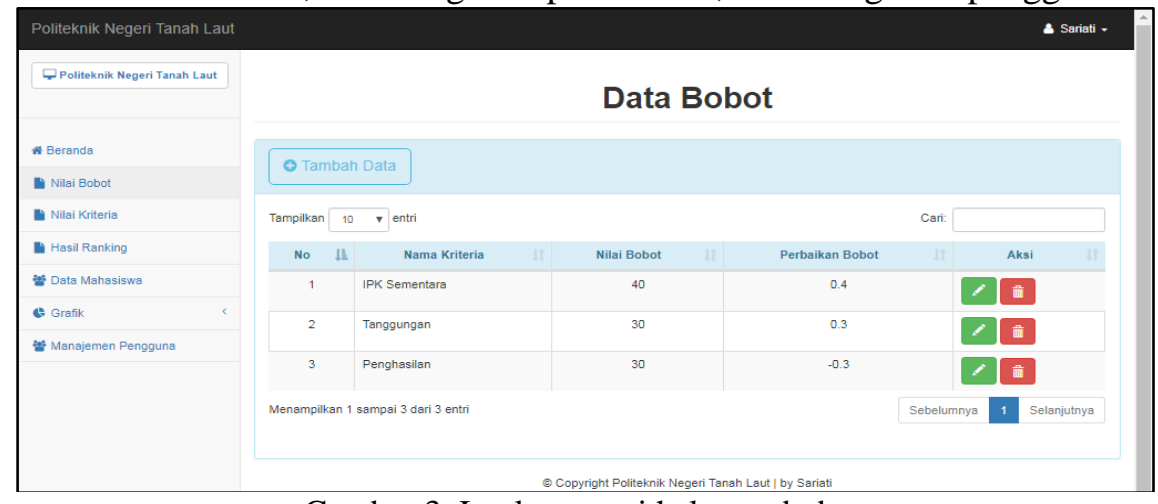

Gambar 3. Implementasi halaman bobot

Gambar 3 menunjukan tampilan halaman data bobot, disini admin dapat mengelola data bobot seperti melihat, menambah, mengubah, mencari serta menghapus data bobot.

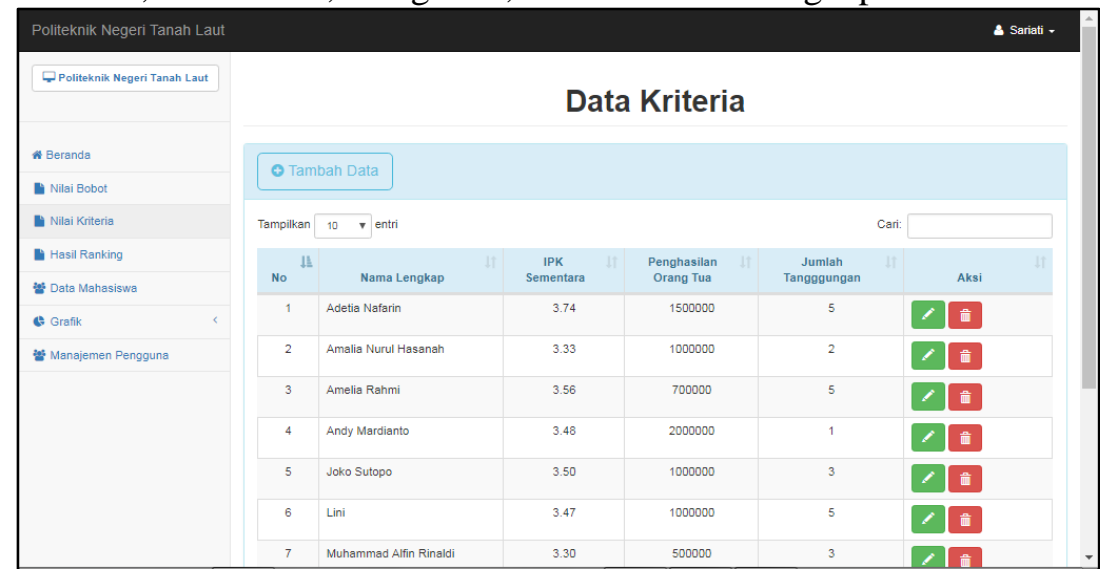

Gambar 4. Implementasi halaman kriteria 
Gambar 4 menunjukan tampilan halaman data kriteria, disini admin dapat mengelola data kriteria seperti melihat, menambah, mengubah, mencari serta menghapus data kriteria.

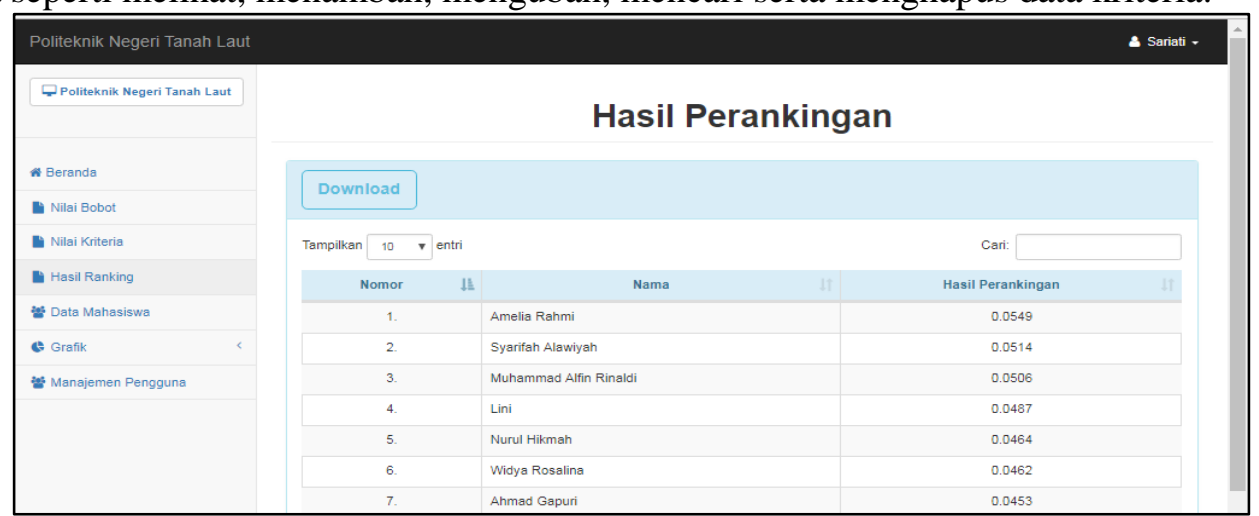

Gambar 5. Implementasi halaman hasil ranking

Gambar 5 menunjukan tampilan halaman hasil ranking sehingga data hasil perhitungan masing-masing mahasiswa berdasarkan nilai kriteria yang telah dimasukkan sebelumnya dapat dilihat oleh admin. Selain dapat melihat secara langsung hasil ranking, admin juga dapat mengunduh laporan hasil perankingan ini.

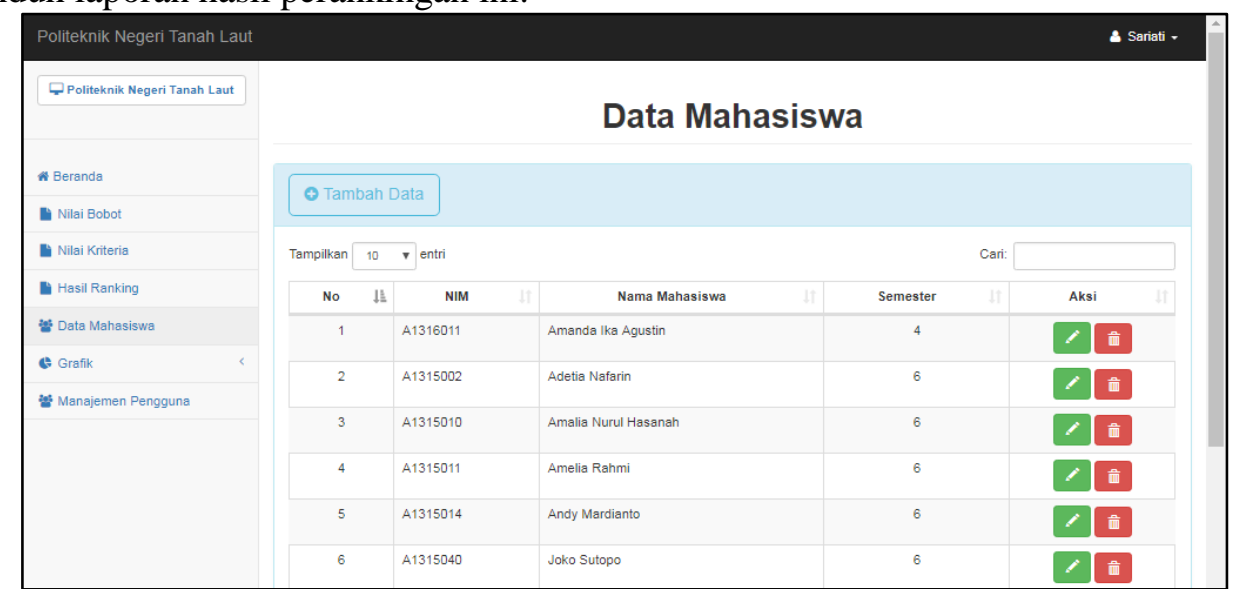

Gambar 6. Implementasi halaman biodata mahasiswa

Gambar 6 menunjukkan tampilan halaman biodata mahasiswa, disini admin dapat mengelola biodata mahasiswa seperti melihat, menambah, mengubah, mencari serta menghapus biodata mahasiswa.

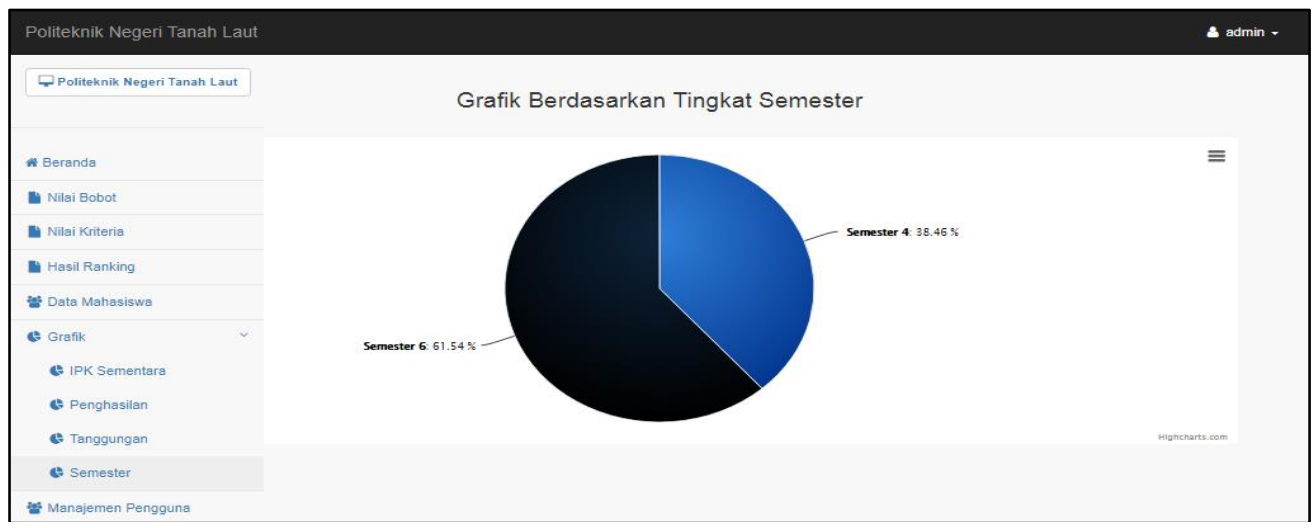

Gambar 7. Implementasi halaman grafik per semester

Gambar 7 menunjukkan tampilan halaman grafik per semester, disini admin dapat melihat jumlah mahasiswa pendaftar beasiswa PPA berdasarkan semester. 


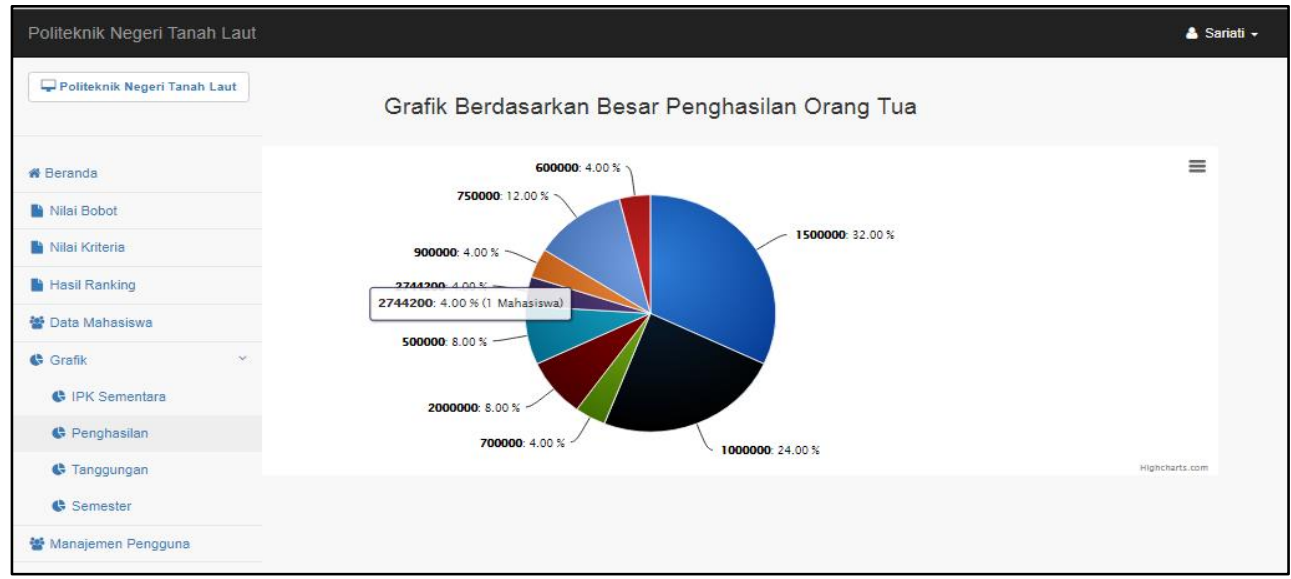

Gambar 8. Implementasi halaman grafik per penghasilan

Gambar 8 menunjukan tampilan halaman grafik per penghasilan orang tua, disini admin dapat melihat jumlah mahasiswa pendaftar beasiswa PPA berdasarkan besar penghasilan orang tua masing-masing pendaftar.

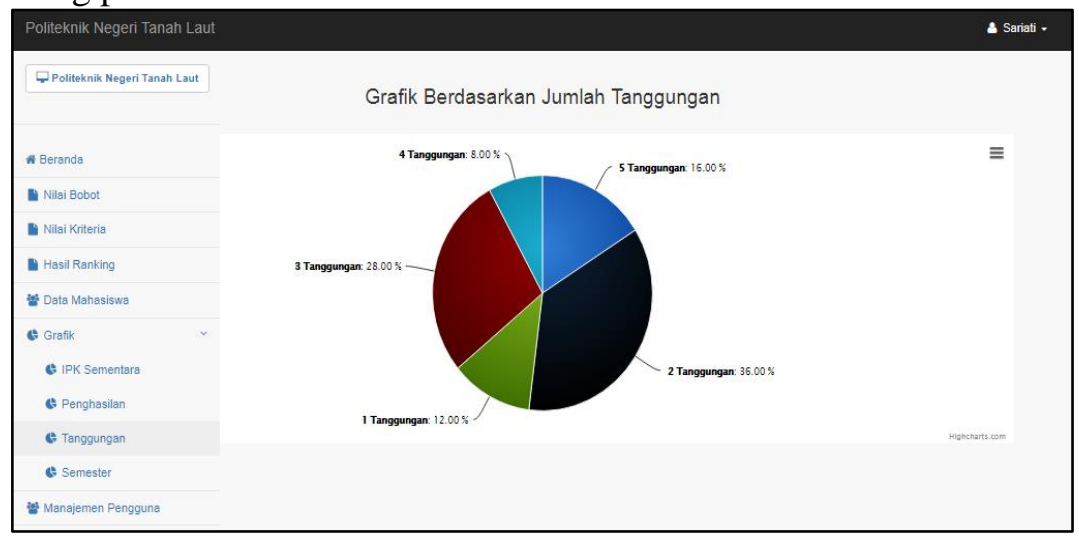

Gambar 9. Implementasi halaman grafik per jumlah tanggungan

Gambar 9 menunjukan tampilan halaman grafik per tanggungan, disini admin dapat melihat jumlah mahasiswa pendaftar beasiswa PPA berdasarkan jumlah tanggungan di masing-masing keluarga pendaftar beasiswa PPA.

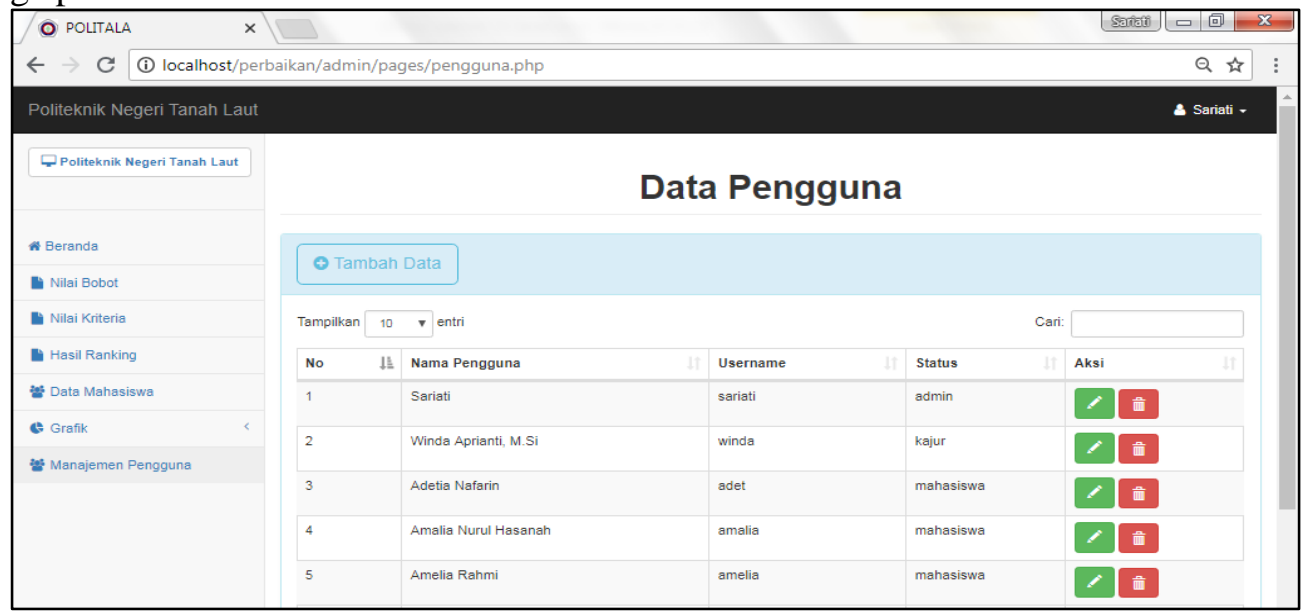

Gambar 10. Implementasi halaman manajemen pengguna

Gambar 10 menunjukan tampilan halaman manajemen pengguna, disini admin dapat mengelola data pengguna seperti melihat data pengguna, menambah data pengguna, mengubah data pengguna, mencari data pengguna tertentu, serta menghapus data pengguna pada sistem ini. 


\section{KESIMPULAN}

Berdasarkan uraian di atas, dapat disimpulkan bahwa penerapan metode weighted product ke dalamsistem pendukung keputusan penerimaan beasiswa PPA yang telah dibangun dapat memberikan informasi hasil perankingan yang dapat membantu kemahasiswaan dan ketua program studi untuk menentukan urutan penerima beasiswa yang memenuhi kuota. Sistem ini juga menyediakan tampilan grafik yang memudahkan pengguna dalam menerima informasi tentang IPK, penghasilan orang tua, jumlah tanggungan dari pendaftar beasiswa PPA. Hal ini berdampak pada pengambilan keputusan yang bersifat objektif bukan karena factor kepentingan pribadi.

\section{DAFTAR PUSTAKA}

Damanik, B. \& Hutagalung, D. M. (2017). Sistem Pendukung Keputusan dalam Pemberian Beasiswa dengan Menggunakan Metode Weighted Product. Journal of Computer Enineering System and Science, Volume 2 (2), 83-87. https://jurnal.unimed.ac.id/2012/index.php/cess/article/view/6413.

Nofriansyah, D. (2015). Konsep Data Mining vs Sistem Pendukung Keputusan. Yogyakarta: CV Budi Itama.

Pratiwi, H. (2016). Buku Ajar Sistem Pendukung Keputusan. Yogyakarta: Deepublish.

Setyawan, A. (2017). Analisis Komparasi Metode Simple Additive Weighting dan Metode Weighted Product pada SPK Rekruitmen Karyawan Baru di PT. Warta Media Nusantara. Skripsi.

\section{Biodata Penulis}

Sariati,lahir di Batu Ampar pada tanggal 14 April 1997. Penulis pertama menyelesaikan Sekolah Menengah Atas pada tahun 2015 dan melanjutkan pendidikan ke Politeknik Negeri Tanah Laut. Saat ini, penulis pertama telah menempuh semester VI di Politeknik Negeri Tanah Laut Jurusan Teknik Informatika.

Winda Aprianti, M.Si, lahir di Martapura pada tanggal 17 April 1990. Penulis kedua memperoleh gelar S.Si dalam bidang Matematika dari Jurusan Matematika Fakultas MIPA Universitas Lambung Mangkurat pada tahun 2011, kemudian melanjutkan pendidikan Strata 2 di Jurusan Matematika Fakultas MIPA Institut Teknologi Sepuluh Nopember Surabaya dan memperoleh gelar M.Si pada tahun 2015. Selama penulis menempuh pendidikan Strata 2, penulis memfokuskan untuk mengkaji bidang komputasi terutama yang berhubungan dengan Data Mining.Setelah memperoleh gelar Magister, penulis bekerja menjadi Dosen di Jurusan Teknik Informatika Politeknik Negeri Tanah Laut mulai tahun 2015.

Fathurrahmani, M. Kom, lahir di Duli pada tanggal 29 Juli 1990. Penulis ketiga menyelesaikan pendidikan Strata 1 di Jurusan Ilmu Komputer Universitas Lambung Mangkurat pada tahun 2013, kemudian melanjutkan pendidikan Strata 2 di Jurusan Ilmu Komputer Universitas Indonesia pada tahun 2015 dan memperoleh gelar M.Kom pada tahun 2017.Setelah memperoleh gelar Magister, penulis bekerja menjadi Dosen di Jurusan Teknik Informatika Politeknik Negeri Tanah Laut mulai tahun 2017. 